Volume: 11 Issue: 1 Year: 2014

\title{
Hiring more officers to fight crime: Evaluation of U.S.'s 100.000 more police officers policy and lessons for Turkey
}

\author{
Kübra Gültekin ${ }^{1}$
}

\begin{abstract}
Crime has been one of the most attention-getting issues for decades. Public administrators, police officials, citizens and media highlight crime stories. Television channels and social media rumors disseminate dramatic crime victimizations. Accordingly, politicians always vocalize policies to fight crime and provide effective policing services. Easiest way to be seen tough on crime is hiring more law enforcement officers. Almost every country, aims to increase number of police officers for security services. It is theoretically expected that more officers enables police agencies to be more effective and successful in fight crime and criminals. Nevertheless, the common belief that hiring more officers makes police agencies more successful in policing services is not evaluated scientifically. Even though, police organizations' potential improves due to increase in personnel, how it reverberated in police practices and in fight against crime is overlooked. This study aims to evaluate the US's 100.000 new police officers policy and implications and lessons for other countries, particularly for Turkey, those employ more officers to fight crime. Findings indicate that more officers will not have substantial effect on crime if human resources are not use efficiently and effectively.
\end{abstract}

Keywords: Crime; Fear of crime; Crime policy; Police officers; Law enforcement efficiency

\section{Introduction}

Crime has been one of the most attention-getting issues (Walker, 2001; Donziger, 1996). Many believe that crime problem is worsening throughout time (Kappeler and Potter, 2005). Media strongly emphasize crime stories by TV series, shows and movies. Politicians and police officials warn people about strangers, rapists, serial killers, violent criminals, and so on. Fear of crime has become one of the most important and debated issue of the society (Gultekin and Gultekin, 2012). Citizens are afraid of crime and want officials and politicians to fight crime and criminals.

\footnotetext{
${ }^{1}$ Assistant Professor, Turkish National Police Academy, kubra.rng@gmail.com
} 
Gültekin, K. (2014). Hiring more officers to fight crime: Evaluation of U.S.'s 100.000 more police officers policy and lesson for Turkey. International Journal of Human Sciences, 11(1), 979-991. doi: 10.14687/ijhs.v11i1.2859

Therefore, politicians give enormous attention to crime issues and place it on their political agenda and campaigns.

Crime issues historically have been one of the several critical presidential campaign issues in the United States. Many presidents, particularly conservatives, focused on crime and passed several important bills regarding the prevention and reduction of crime. Some democrat presidents also supported and passed tough crime bills due to political concerns. President Clinton was one of them. He promised about putting 100.000 more police officers into the streets in his presidential campaign since he believed that only "more police, more prevention, tougher penalties" could deal with nation's crime problem (Grey, 2000). After elections, he strongly supported and passed the Violent Crime Control and Law Enforcement Act in 1994.

This work aims to address and evaluate President Clinton's adding 100.000 more police officers by the Violent Crime Control and Law Enforcement Act of 1994. To do so, first, a brief discussion of crime issue will be stated. What the real intent of the policy was, how it came to agenda, how it was formulated, how it was implemented and evaluated will be discussed. Finally, lessons for the other countries, particularly for Turkey, will be examined even though results of a particular policy are hard to draw conclusions for other countries. Nevertheless, mistakes made and actions took certainly imply inferences for Turkey since Turkey seems to hire more officers to be effective in law enforcement. Accordingly, this study aims to develop recommendations for Turkey as a country that hires more than 110.000 law enforcement officers in a ten-year period (Akşam, 2014). Police agencies in the US hired a comparable number for law enforcement purposes in the content of President Clinton's the Violent Crime Control and Law Enforcement Act over eight year period.

\section{Background}

Crime in the United States is always considered an attention-getting and debatable issue (Kappeler and Potter, 2005; Walker, 2001; Donziger, 1996). Conservatives have been recognized for their tough stance against crime and have always tried to keep the issue of crime on the agenda. The claim that the crime problem is worsening every day is one of the most spoken-issues across the country. Even though serious crime rates have significantly declined for many years, public concern about crime seems persistent. This is due to the media and its reflection of crime, law enforcement agencies claims, and political manipulation of crime (Kappeler and Potter, 2005). Many police departments report high crime rates so that they can get larger budgets, more high-tech equipments and more police officers (Donziger, 1996).

The history of sensibility regarding crime issue among politicians goes back to the 1960s. During the 1960s, it was showed by the Federal Bureau of Investigation (FBI) Uniform Crime 
Gültekin, K. (2014). Hiring more officers to fight crime: Evaluation of U.S.'s 100.000 more police officers policy and lesson for Turkey. International Journal of Human Sciences, 11(1), 979-991. doi: 10.14687/ijhs.v11i1.2859

Reports that the crime rate was dangerously increasing among American society. After that, crime issue became one of the key issues of political campaigns in the country. President Johnson established famous 'the President's Commission on Law Enforcement and the Administration of Justice'. According to the Commission's report, The Challenge of Crime in a Free Society, the federal government should provide financial assistance to state and local governments to overcome crime problem since crime is not only a local problem but also a nationwide problem. Hence, President Johnson provided grants for state and local governments concerning law enforcement efforts. Congress passed the Omnibus Crime Control and Safe Streets Act, which granted federal money for law enforcement purposes including recruitment of law enforcement personnel, in 1968. Law Enforcement Assistance Administration (LEAA) was established due to the Omnibus Crime Control and Safe Streets Act. With the establishment of LEAA, federal government progressively more involved in local level law enforcement. After that, The Comprehensive Crime Control Act of 1984 and The Crime Control Act of 1990 was passed in Congress. They also supported federal assistance to states regarding law enforcement issues (O’Bryant, 2003). And then, Clinton's The Violent Crime Control and Law Enforcement Act of 1994 came into the public eye.

Obviously, crime has been perceived as a critical issue to get votes in elections. This was especially the case after the 1988 elections campaigns that Michael Dukakis lead in the beginning. Dukakis was the governor of Massachusetts, where a successful furlough system had been implemented. However, a participant of the furlough program, Willie Horton, committed a violent crime while he was on furlough. George $\mathrm{H}$. Bush, the republican presidential candidate, used this single issue to insinuate that Dukakis, the democrat presidential candidate, was soft on crime. Bush capitalized on this event in his campaign; a black person committed a crime against white females because of the soft criminal justice system. Consequently, front-runner Dukakis lost the elections (Kappeler and Potter, 2005; Toner, 2004; Simon, 2002; Walker 2001; Donziger, 1996). Since then, every presidential candidate, including democrats and tough conservatives, has been trying to be looked tougher on crime. Therefore, the presidents support media, interests groups, and bureaucrats' strict and rigid crime policies.

Consequently, the country was introduced to new and tougher crime policies and bills throughout time. For example, it is assumed that when a person was caught in 1992 due to a drug offense, he/she was five times more likely to be imprisoned than if he/she was caught in 1980. Not surprisingly, though criminal punishments has been applied to even for petty offenses (Donziger, 1996). These are results of social construction of crime by the media, politicians, bureaucrats, and interests groups. It should also be emphasized that citizens buy this construction without questioning whether it is authentic or mythical. 
Gültekin, K. (2014). Hiring more officers to fight crime: Evaluation of U.S.’s 100.000 more police officers policy and lesson for Turkey. International Journal of Human Sciences, 11(1), 979-991. doi: 10.14687/ijhs.v11i1.2859

\section{Agenda}

The law enforcement issues are a good target on which to make a policy since it gets attention due to the police institutions' importance. This is so because the police "have the power to decide how to apply the law and determine the crime-fighting agenda of a community" and they occupy a frontline position among criminal justice apparatus since they arrest or jail about 11 million people every year (Donziger, 1996, p.161). Therefore, adding more police officers is considered good politics. Similarly, democratic presidential candidate William Clinton has been affected by this increasing trend, even among democrats. That is the reason Clinton supported hiring or rehiring new police officers. He promised to be tough on crime and add 100,000 more police officers to fight crime and criminals. When he was elected and came to power, he kept his promise of more officer policy. The Violent Crime Control and Law Enforcement Act was passed by Clinton's passionate and willingly efforts.

The Violent Crime Control and Law Enforcement Act of 1994 authorized approximately $\$ 9$ billion dollars to provide for 100,000 more police officers by hiring new officers or rehiring laidoff ones. The aim was to enhance community-policing efforts since community policing was an increasingly attention-getting police strategy to deal with crime, criminals, and crime-ridden neighborhoods. Indeed, putting more police officers on the streets was extremely popular at that time. Bureaucrats, the media and interest groups were supporting to employ more police officers. It was believed that more police would increase the effectiveness of community-oriented policing. The reasoning that underlies this assumption presumes that increased number of officers causes more police patrols and that reduces the crime rates. Both African-Americans and Whites tended to see more police officers on the streets (Walker, 2001). The media was full of crime stories. Fear of crime was an important public characteristic in that time. Therefore, Clinton enthusiastically backed the act and provided funding for an increasing number of police officers across the country. The logic behind this policy was to deter crime and catch criminals by simply adding more cops on the streets because it is widely believed that more police means less crime.

\section{Formulation}

The Violent Crime Control and Law Enforcement Act of 1994 specified some of the ways that the money should be used. For example, according to the act, some of the money should be spent to rehire law enforcement officers that have been laid-off due to state and local budget reductions for deployment in community-oriented policing. Similarly, a part of the funding could be used to hire and train new career police officers for employment in community-oriented policing initiatives across the country. It can be easily realized that employing an additional 100,000 police officers is a result of community- oriented policing. Therefore, community-oriented policing serves as a 
Gültekin, K. (2014). Hiring more officers to fight crime: Evaluation of U.S.'s 100.000 more police officers policy and lesson for Turkey. International Journal of Human Sciences, 11(1), 979-991. doi: 10.14687/ijhs.v11i1.2859

legitimization means for putting additional police officers into police agencies. The policy, in other words, is formulated to employ new officers for particular purposes.

\section{Legitimizing}

The Violent Crime Control and Law Enforcement Act was passed in 1994 in Congress with the votes of both parties, democrats and republicans. Even though the proposal was supported by government, republicans did not oppose it because such conservative polices have been republicans' traditional standpoint throughout a long time. Therefore, the majority of Congressmen voted for the bill and passed it in 1994. Accordingly, it can be said that the Violent Crime Control and Law Enforcement Act was legitimized through a legislative legitimization process.

The objective of the law was fighting and overcoming violent crime: "by increasing the number of police with advanced education assigned to community patrol in areas of great need, and to provide educational assistance to students who possess a sincere interest in public service through law enforcement and to law enforcement personnel" (http:// 12.46.245.173/pls/portal30/catalog.program_textrpt.show?p_arg_names=prog_nbrandp_arg_valu es=16.712). On the other hand, the grant for the bill was passed in February, 1995. The fund was enacted by the Senate and House of Representatives in Congress assembled. Thus, the federal money was provided for local governments to hire 100.000 police officers and support communityoriented policing activities.

\section{Implementation}

The fund for local government would be paid by the Director of the Bureau of Justice Assistance, according to Local Government Law Enforcement Block Grants Act of 1995. However, usage was subject to some provisions. The money could be used only for reducing crime and improving public safety, which was including hiring, training, and employing new law enforcement officers, paying overtime to presently employed officers, providing equipment and technology, enhancing security measures, establishing and supporting drug courts, establishing prevention programs for juvenile crimes, establishing cooperative task forces between units of local governments, and establishing crime prevention programs (http://www.usdoj.gov).

All States were eligible to submit a State plan to get money from the fund. State and local police forces who are participating state plans could be provided federal money. The bill stated even specifics of those who can be hired according to this particular law (http://www.usdoj.gov).

More than 100.000 police officers have been hired as a result of the Violent Crime Control and Law Enforcement Act until President Bush stopped the program (Weiner, 2005). However, the implementation of this policy seems problematic. Even though the additional 100.000 police officers and $\$ 9$ billion dollars were thought to reduce crime, the money and personnel was largely 

lesson for Turkey. International Journal of Human Sciences, 11(1), 979-991. doi: 10.14687/ijhs.v11i1.2859

hired for suburban and small-town police agencies where crime is usually not as problematic. The problem will be more perceptible when it is realized that there are more than 17.000 separate police departments all over the country (Donziger, 1996). However, the crime problem is more visible and the Violent Crime Control and Law Enforcement Act is more serious in urban neighborhoods. Therefore, the grant and 100.000 police officers should theoretically be added to the largest cities. Nevertheless, the General Accounting Office (GAO) released that seventy-seven percent of the grant for this policy was used for suburban and small-town police organizations (Walker, 2001). Similarly, the Maryland Preventing Crime Report suggests that crime-control efforts should be concentrated on urban places since youth violence primarily occurs in metropolitan neighborhoods (Sherman, 1997). Accordingly, it can be said that 100.000 additional police officers did not significantly affect the crime problem all over the country.

In addition, a substantial portion of the newly hired police officers weren't used in crime reduction programs. Even though police departments got federal funding for hiring new officers for community policing, some of those departments did not apply to community policing. Correspondingly, though some police departments applied to community policing, they did not change their traditional police operations in the context of reducing crime and citizens' fear of crime (Walker, 2001). Hence, the implementation of the policy does not reflect the real purpose of the policy. Consequently, the implementation appears problematic.

On the other hand, with respect to implementation problems, it is declared that community policing has reduced reported crimes (Donziger, 1996). However, the lack of scientific data and research in which we can see whether or not new police officers hired due to the Violent Crime Control and Law Enforcement Act affected this reduction. In the light of the information we have, it can be said that not simply adding more police officers but focusing on the community policing by narrowing it may work in the name of crime prevention (Walker. 2001; Donziger, 1996).

Bovard (2000) makes another implementation problem visible. He believes that the federal money is spent on useless things in the name of public safety. He claims that there is no correlation between the federal grant for Clinton's 100,000 more police officers policy and crime rates since 1993. Considering most of newly hired officers are employed by police agencies with crime problem not as serious, it can be said that money is used by individual states not as intended.

\section{Evaluation}

The Violent Crime Control and Law Enforcement Act of 1994 (P. L. 103-322) authorized funding for law enforcement and crime prevention measures including increasing the number of crimes punishable by death and establishing a "three-strikes" provision for violent offenders. Since the 
Gültekin, K. (2014). Hiring more officers to fight crime: Evaluation of U.S.'s 100.000 more police officers policy and lesson for Turkey. International Journal of Human Sciences, 11(1), 979-991. doi: 10.14687/ijhs.v11i1.2859

enactment of the last major crime control bill, many bills have evolved to further address crime and criminal justice issues.

There are numerous myths about the number of police and crime reduction. First, more officers does not mean that they will be assigned as patrol officers on the streets. It is very critical that police agencies use their officers differently. Even though Brann (1997), the director of the Office of Community-Oriented Policing Services (COPS) of the U.S. Department of Justice, says that 100,000 additional police officers will not be behind desks, a substantial portion of police officers spend the bulk of their time in regular bureau and desk jobs and administrative tasks rather than fighting street crimes (Donziger, 1996). Second, the number of police officers, solely itself, does not have a positive effect on crime. This is so because according to Bureau of Justice Statistics' Law Enforcement Management and Administrative Statistics of 1997, Washington D.C. has more than four times as many police officers as San Diego; however, it scarcely makes the city safer (Walker, 2001).

Third, even if more police officers are assigned for street jobs, it may not have any effect on crime and reduction of fear of crime. If police officers are used in two-officer patrols, it does not make any impact on crime (Walker, 2001). Fourth, what police officers do while they are on the streets also should be taken into account. For example, if police officers assigned to street jobs do not do real police work or do what they have been doing; assigning more officers does not make any difference in crime reduction. This is so because police officers on the streets do not spend the majority of their time fighting with crime. Police work, indeed, is quite routine since police spend a substantial portion of their time on mundane tasks such as writing traffic tickets, investigating automobile accidents, governing traffic, mediating conflict between people, and engaging in other service related daily tasks (Kappeler and Potter, 2005; Donziger, 1996). Fifth, the traditional presumption that more police patrol prevents, or at least reduces crime, should be questioned. This idea has been accepted for many decades, even for more than one century, since the first police organization in London in 1829 (Walker, 2001).

However, the Kansas City Preventive Patrol Experiment proved just the opposite; more patrol does not make any difference on crime rates. In this experiment, the southern district of the city was divided into three parts in which different patrolling strategies were applied for one year. At the end of the experiment, it was realized that the level of patrol has no affect on crime and citizens' perception of crime. The part that applied more patrol did not reflect crime reduction. Similarly, the part with less police patrol did not increase crime. Most interestingly, citizens did not perceive the differences (Kappeler and Potter, 2005; Walker, 2001; Donziger, 1996). Similarly, Fritsch, Caeti, and Taylor (2003) conducted research in Dallas regarding increasing the number of 
police patrol and they discovered that police patrol has a little impact on reducing crime, which shows that simply increasing police officers in the streets is not an effective way to overcome the crime problem. (Fritsch, Caeti, and Taylor, 2003).

Nevertheless, it should be emphasized that this result should be read more carefully because it does not indicate that patrolling does not have any impact on crime and citizen perceptions. According to the rational choice theory, people do make rational choices. For example, if people and potential criminals see patrol officers and police cars around, they assume that there is always police patrol even if they do not see them at a particular time. This is a threat for them to be caught. Therefore, the potential criminals are expected to make rational choices and not commit crime due to police presence. However, many criminals and potential criminals do not consider police patrols threatening and believe that they will not be caught. Moreover, patrolling styles are important because a patrol car passes a particular place repeatedly very few times in a week. This may not cause a deterrence effect. Likewise, some crimes including homicide and rape are not affected by patrolling since they are not suppressible by patrolling whereas some others, including robbery and auto theft, are suppressible by patrolling (Walker, 2001).

The policy of 100,000 more officers has another side effect. According to Farah (1999), the police frequently engage in deviant behavior. Therefore, more police means more deviance: "Americans are losing their freedoms, their civil liberties, their individual rights as a result of this trend and others concentrating more power in the hands of the few. We are in danger of becoming a police state led by a demagogue with no respect for the Constitution or the rule of law... The only true deterrent to crime and tyranny is a vigilant armed populace. Police can't possibly protect you from most crimes. The best they can do is to take a report, perform a cursory investigation after you've been victimized and, perhaps, apprehend a criminal who has already deprived you of life, liberty and property." According to this vies, more police officers on streets can be threat to individual freedoms and civil liberties.

\section{Implications and Lessons for Turkey}

Turkey, as a candidate country for European Union and rising power in its region and around the world, places considerable importance to security issues. Not only regional and global security but also internal security and law enforcement has been one of the most important issues discussed in the country. Every year, the country hires thousands of cadets for law enforcement agencies (Aksam, 2014; Sabah, 2014). According to the Minister of Interior of Turkey, the country has employed more than 110.000 cadets for law enforcement (Akşam, 2014) in last ten years. Obviously, averagely more than 10.000 cadets are recruited each year. These numbers are significant. Considering the total number of the personnel of Turkish National Police is around 
Gültekin, K. (2014). Hiring more officers to fight crime: Evaluation of U.S.'s 100.000 more police officers policy and lesson for Turkey. International Journal of Human Sciences, 11(1), 979-991. doi: 10.14687/ijhs.v11i1.2859

265.000, the increase for every year seems noteworthy. Such an increase is expected to have vast influence on crime rates and fear of crime among citizens. However, some scholarly studies illustrate opposing results (see Arslan and Ocal, 2012; Erzurumluoğlu and Göksu 2009).

Simply increasing the number of police officers, as noted above, does not mean that police agencies will have more officers on streets to fight crime and criminals. More police officers does not necessarily lead more effectiveness in law enforcement services. This means that effective and efficient use of police forces is more important and more beneficial for law enforcement agencies in terms of policing services than just adding new officers to the force.

To increase the number of law enforcement officers does not assure more force to fight crime and criminals particularly urban settlements with high crime rates. As seen in the US case, most of the time officers are appointed in bureau tasks. Turkish National Police has a similar problem. Many law enforcement officers are appointed in bureau tasks in which law enforcement skills are not needed. For example, many officers are recruited in police guest houses all around the country. Some of them work as receptionists, some work in restaurants and some in canteens. Some law enforcement officers selects appropriate foods (cheese, olive, tomato etc.) for guests at the police guests houses. Obviously, these tasks do not require law enforcement skills and necessitate other specialties which most of the time law enforcement officers do not have.

This illustrates an important problem of efficiency since number of officers is considered as a vital input for policing services (Ulkemen and Gultekin, 2010). Many studies regarding police efficiency focuses on number of police officers (see Sun, 2002; Verma and Gavirneni, 2006). Law enforcement officers are trained and skilled to provide policing services and assistance to the public. Law enforcement services are in many cases requires technical skills. That is the reason cadets are trained intensively prior to policing on the streets. Training cadets and paying officers is not low-priced for the country. However, many officers are appointed non-crime related tasks such as accounting, food, storage, subsistence, transportation, and other non-law enforcement tasks. These services can be contracting out or can be provided by other low-paid bureaucrats. The police agency can hire civilians to provide such services. Even though some civilians are hired for some tasks many non-law enforcement tasks are still provided by police officers. This is simply an inefficient use of human resources. As Bovard (2000) highlights, country's money is spent in nonlaw enforcement services in the name of policing services.

In addition, evaluating how new officers are deployed is an overlooked issue in Turkey. Whether new officers are hired for high crime areas and significant law enforcement issues is a controversial subject. For example, most citizens interact with police agency through officers in police stations and traffic services. Nevertheless, police stations usually complain about lack of 
Gültekin, K. (2014). Hiring more officers to fight crime: Evaluation of U.S.’s 100.000 more police officers policy and lesson for Turkey. International Journal of Human Sciences, 11(1), 979-991. doi: 10.14687/ijhs.v11i1.2859

enough officers particularly in large urban cities. Similarly, if a citizen experiences a car accident, traffic police forces sometimes attend accident area more than one hour later even in the capital city of the country. This shows that hiring more officers does not guarantee faster and more effective policing services. More officers do not mean more patrol officers on the streets. When a police building is visited, one can easily see that many officers work behind desks and perform nonpolicing works and administrative tasks instead of fighting crime on the streets. As seen in Walker's (2001) Washington D.C. vs. San Diego comparison, the number of police officers, solely, does not have a positive effect on crime. Many cities with high police officer ratio are not as safe as cities with low police officer ration.

Another inefficiency problem with Turkey's increasing police officer ratio is appointing more officers for even simple tasks. For example, in the US, two-officer patrols are criticized and have been shown as a sign of inefficiency use of officers and money. Nevertheless, one can easily see patrol cars with three-officers in Turkey. Many officers are required to come to work area for social events such as soccer games and public demonstrations several hours earlier than the event. Since the organization does not pay extra many for working over time, officers can be subject to extensive on standby time for the task. Unnecessary deployments and 'second order' practices, even in superfluous times, decrease morale and motivation of police officers as well as their job satisfaction and organizational commitment.

Evaluation of how new officers are appointed and how they influenced the policing practices should be placed more importance in Turkey. More officers must indicate faster, more effective and better law enforcement services. More officers should reduce fear of crime among citizens. Nonetheless, the number of studies about fear of crime in Turkey is simply scarce (Dolu, Uludağ and Doğutaş, 2010). Although fear of crime affects society and policing services, it does not have a place on organizational and political agenda (Uludağ, 2010). Thus, whether more officers lead to reduction in fear of crime is an important question for Turkish National Police. To do so, time series analyses and more scholarly inquiries are needed.

Many problems regarding inefficient use of new law enforcement officers are related to accountability problem in public sector. Turkish public administration has a highly centralized administration structure and secrecy is an important underlying principle (Gul, 2008). Organizations most of the time keep data for internal use only and data collection is not diversified (Polat, 2008). Audits do not seem effective (Zengin, 2012). Human resources principles for police leaders are not strictly predetermined. Arbitrary and inefficient use of law enforcement personnel is not measured and not inspected regularly and genuinely. Problems with accountability in public sector and law 
Gültekin, K. (2014). Hiring more officers to fight crime: Evaluation of U.S.'s 100.000 more police officers policy and lesson for Turkey. International Journal of Human Sciences, 11(1), 979-991. doi: 10.14687/ijhs.v11i1.2859

enforcement agencies make effective and efficient use of newly hired officers to fight crime and provide safer environments for citizens.

Moreover, fighting crime and criminals does not only require more officers but also new methods to police better. Turkish police needs to employ new approaches to fight crime and criminals. Hiring more officers can contribute to effectively provide secure environments but does not assure. Hence, community policing style approaches should be implemented. Such practices, as Delice and Duman (2012) note, must be consistently measured and evaluated. Without constant evaluation, effectiveness, problems and things-need-improvements cannot be realized and necessary actions cannot be taken.

\section{Conclusion}

It can be concluded that simply adding more police officers to police organizations may be a waste of money. Even though the purpose of lawmakers seems understandable and politically intelligent, spending billion dollars to hire new officers has not made any difference on crime and fear of crime among citizens. Even though crime rates in general tend to decrease despite the widespread perception that crime continues to increase, we lack experimental research results to relate it with an increasing number of police officers. On the contrary, studies show that crimes reported to the police tend to decrease in recent years notwithstanding the relative increase in number of the police on the streets (Kappeler and Potter, 2005). However, it is expected that more police on streets make reporting crimes to the police easier.

On the other hand, it should always be taken into account that reports regarding crime rates by police agencies are subject to political and organizational exploitation due to political and organizational priorities since it is believed that crime is a profitable issue. Therefore, "it is the interests of police administrators, prison officials, judges, [politicians] and prosecutors to keep crime in the forefront of public debate. Enormous sums of money, millions of jobs, [millions of votes] and bureaucratic survival depend on increasing concerns about crime"; however, this not only involves more jobs and large budgets but also policy decisions and jurisdictional concerns play an important role regarding police officials constant and exaggerated emphasis on crime (Kappeler and Potter, 2005, p.49). That is the reason, despite approximately a $\$ 100$ billion annual expenditure in the US (Christie, 2000; Donziger, 1996) on crime, there has not been much accomplished so far (Kappeler and Potter, 2005). Therefore, how to police better and effectively deal with crime, criminals and fear of crime among citizens should have been strongly emphasized. Principally, available police personnel should have been used effectively before simply adding more police. As a police chief points out "we don't need more police. We need to police better" (Donziger, 1996). 
Gültekin, K. (2014). Hiring more officers to fight crime: Evaluation of U.S.'s 100.000 more police officers policy and lesson for Turkey. International Journal of Human Sciences, 11(1), 979-991. doi: 10.14687/ijhs.v11i1.2859

Hence, police organizations need to use human resources more efficiently instead of augmenting the number of officers.

\section{References}

http://thomas.loc.gov/cgi-bin/query/F?c103:1:./temp/ c103Z58wPs:e39252

http://www.usdoj.gov/

http://12.46.245.173/pls/portal30/CATALOG.PROGRAM_TEXT_RPT.SHOW?p_arg_names $=$ prog_nbrandp_arg_values $=16.712$

Aksam (2014). 2014'te 11 bin polis alınacak. Retrieved March 07, 2014 from http://www.aksam.com.tr/guncel/2014te-11-bin-polis-alinacak-c2/haber-261445

Aslan, A. and Ocal, O. (2012). Türkiye'de Suç Oranlarının Yüksekliğii (The Analysis Of Persistence In Crime Rates In Turkey). Nigde Universitesi İ̈BF Dergisi, 5 (1), 85-92.

Bovard, J. (2000). Laptops to the Rescue. Retrieved April 04, 2006 from http://www.fff.org/freedom/1200d.asp

Brann, J.E. (1997). Cops: Partnership with coummunities. Retrieved April 04, 2006 from http://usinfo.state.gov/journals/itdhr/1197/ijde/brann.htm

Christie, N. (2000). Crime control as industry (5th ed). New York, NY: Routledge.

Delice, M. and Duman, A. (2012). Toplum Destekli Polislik Kapsaminda Halkin Polis Algisinin Ölçülmesi: Erzurum İli Örneği (The Measurement of Citizens' Police Perception in the Context of Community Policing: The Case of Erzurum City). Journal of Police Studies, 14 (2), pp.1-31.

Dolu, O., Uludağ, Ş. ve Doğutaş, C. (2010).Suç Korkusu: Nedenleri, Sonuçları ve Güvenlik Politikaları İlişkisi. Ankara Üniversitesi Siyasal Bilimler Fakültesi Dergisi, 65, (1), p.57-81

Donziger, S.R. (1996). The real war on crime: the report of the National Criminal Justice Commission. New York, NY: HarperCollins Publishers, Inc.

Erzurumluoğlu, B. and Göksu, T. (2009). Türkiye'deki Suç Eğilimleri ve Polis Performansinin Faktörel Etkisi. (Crime Trends and Factorial Effects of Police Performance in Turkey). Turkish Journal of Police Studies, 11 (3), 43-60.

Farah, J. (1999). Do we need 100,000 more cops? Retrieved April 24, 2006 from http://www.wnd.com/news/article.asp?ARTICLE_ID=14663

Fritsch, E. J., Caeti, T. J., and Taylor, R. W. (2003). Gang suppression through saturation patrol and aggressive curfew and truency enforcement: A A quasi-experiment test of the Dalls anti-gang initiative. In S.H. Decker (Ed.), Policing gang and youth violence (pp. 267284). Belmont, CA: Wadsworth.

Grey, B. (2000). The Million Mom March: the social and political issues that were not addressed. Retrieved April 04, 2006 form www.wsws.org

Gul, S. K. (2008). Kamu Yönetiminde ve Güvenlik Hizmetlerinde Hesap Verebilirlik. Journal of Police Studies, 10 (4), p.71-94

Gultekin, K. and Gultekin, S. (2012). Is juvenile boot camp policy effective? International Journal of Human Sceinces, 9 (1), pp. 725-740.

Kappeler, V. E. and Potter, G. W. (2005). The mythology of Crime and criminal justice (5th ed). Long Grove: IL, Waveland Press.

O’Bryant, J. (2003). Crime Control: The Federal Response. Retrieved April 05, 2006 from http://usinfo.state.gov/usa/infousa/society/crime/crimegun1.pdf

O'Bryant, J. and Seghetti, L. (2002). Crime Control: The Federal Response. Retrieved from http://www.policyalmanac.org/crime/archive/crs_federal_crime_policy.shtml

Polat, A. (2008). Suç İstatistiklerine İlişkin Sorunlar ve Öneriler. Journal of Police Studies, 10 (1), p. 1 24. 
Gültekin, K. (2014). Hiring more officers to fight crime: Evaluation of U.S.'s 100.000 more police officers policy and lesson for Turkey. International Journal of Human Sciences, 11(1), 979-991. doi: 10.14687/ijhs.v11i1.2859

Sabah (2014). 30 bin yeni polis geliyor! Retrieved March 07, 2014 from http://www.sabah.com.tr/Gundem/2012/06/18/emniyet-teskilatina-30-bin-polismemuru.

Sherman, L. W. (1997). Policing for Crime Prevention. In Preventing Crime: What Works, What Doesn't, What's Promising (chapter eight). Retrieved from http://www.ncjrs.gov/works/chapter8.htm

Simon, R. (2002). The Campaign Games Begin in U.S. News and World Report, 00415537, 2002, Vol. 133, Issue 25.

Sun, S. (2002). Measuring the Relative Efficiency of Police Precincts Using Data Envelopment Analysis. Socio-Economic Planning Sciences, 36, pp. 51-71.

The United States Department of Justice, the Financial Guide 2002.

Toner, R. (2004). Swift Boats and the Lessons of Dukakis. Retrieved April 04, 2006 from http://www.freerepublic.com/focus/f-news/1201883/posts

Ulkemen, S. and Gultekin, S. (2010). Measuring The Relative Efficiency Of City Police Departments In Turkey By Using Data Envelopment Analysis. Journal of Police Studies, 12 (2), p.125-144.

Uludağ, S. (2010). Vatandaşlarin Suç Korku (Güvenlik Endişesi) Seviyesine Etki Eden Faktörler ve Alinabilecek Önlemler: Malatya Örneği (Factors Affecting Citizens' Fear of Crime and Precautions: Malatya Case). Journal of Police Studies, 12 (1), p.1-28.

Walker, S. (2001). Sense and nonsense about crime and drugs: A policy guide. Belmont, CA: Wadsworth/Thompson Learning.

Verma, A. and Gavirneni, S. (2006). Measuring Police Efficiency in India: An Application of Data Envelopment Analysis. Policing: An International Journal of Police Strategies and Management, 29 (1), pp.125-145.

Weiner, A. (2005). Keeping New Yorkers safe and secure: An active approach to keeping New Yorkers safe and secure. Retrieved from http://www.anthonyweiner.com/speeches/show/8

Zengin, C. (2012). Polis Eğitim Fonksiyonunun Yönetsel Performansinin Değerlendirilmesi: Tematik Denetim Yönteminin Uygulanabilirliği (Performance Evaluation of Police Training Function: The Applicability of Thematic Inspection Methodology). Journal of Police Studies, 14 (1), pp.101-134. 